\title{
Dividend Policy and Agency Effects: A Look at Financial Firms
}

\author{
Eric Haye ${ }^{1}$ \\ ${ }^{1}$ Anisfield School of Business, Ramapo College of New Jersey, USA \\ Correspondence: Eric Haye, Anisfield School of Business, Ramapo College of New Jersey, Mahwah, NJ 07430, \\ USA. Tel: 1-201-684-7347. E-mail: ehaye@ramapo.edu
}

Received: October 29, 2013

Accepted: November 22, $2013 \quad$ Online Published: January 23, 2014

doi:10.5539/ijef.v6n2p8

URL: http://dx.doi.org/10.5539/ijef.v6n2p8

\begin{abstract}
This paper attempts to determine the relationship between the dividend policy of financial firms and a number of ownership and board control variables as well as two governance provisions-cumulative voting and staggered boards. Agency theory contends that dividends can be used as a substitute control device when ownership, board or governance provisions are unfavorable for shareholders. The evidence indicates that firms with lower CEO, institutional and hedge fund ownership pay higher dividends. Also, cumulative voting has a greater impact on dividend policy than staggered boards. These results suggest that firms adjust their dividend policy in response to control changes caused by ownership structure and governance provisions.
\end{abstract}

Keywords: dividend policy, corporate governance, staggered boards, ownership structure, independent directors

\section{Introduction}

One factor that may play an important role in determining corporate dividend policy is agency theory. Agency theory posits that dividends encourage managers to more efficiently use available resources (Jensen, 1986). Dividends may also require firms to obtain external funding to completely meet their budgeting requirements, subjecting them to the scrutiny of the capital markets (Easterbrook, 1984). In this context, the dividend serves as a disciplining and monitoring mechanism intended to reduce the agency costs of equity. If not anticipated, shareholders bear the burden of these costs. Corporate charter provisions, board structure and ownership structure serve as potential sources of agency conflict. Shareholder-unfriendly corporate governance provisions, inadequate independent board member representation, sparse executive shareholdings and/or diffusely-held outsider shareholdings all potentially impair shareholder control and foster managerial entrenchment.

Corporate governance provisions affect the degree of control that shareholders exercise over executive decision-making and corporate activities, with consequences on a firm's dividend policy. The theoretical relationship between the legal protection offered by corporate governance provisions, shareholder control and dividend policy may be characterized by one of two competing hypotheses - the outcome (or managerial entrenchment) model and the substitution model (LaPorta et al., 2000). Firms with governance provisions that attenuate shareholder control enable managers to divert discretionary cash flow toward negative-net present value spending proposals, or to engage in activities, such as unproductive acquisitions, diversification programs or cash-hoarding strategies, that may enhance managerial prestige or job security but erode share value (Jensen, 1986). The outcome model predicts that these firms will pay lower dividends. Alternatively, shareholders empowered by legal protections that secure strong governance rights can compel insiders to pay higher dividends. There is empirical evidence supporting the outcome hypothesis. Jiraporn, Kim and Kim (2011) find that firms with strong shareholder rights are more likely to pay a dividend, and dividend-paying firms with strong shareholder rights tend to pay higher dividends. Examining a sample of Canadian firms, Adjaoud and Ben-Amir (2010) find a positive association between shareholder rights and dividends.

The substitution hypothesis contends that shareholder rights and dividend payout serve as alternate control mechanisms. Managers of firms with weak governance structures have an incentive "to establish a reputation for moderation in expropriation of shareholders" in order to raise external financing under favorable terms should the need arise (Laporta et al., 2000). One way of establishing a good reputation is through the payment of dividends. In support of the substitution hypothesis, Jo and Pan (2009) find that firms with entrenched managers have a higher propensity to pay dividends. Jiraporn and Ning (2006) find that firms use dividends in place of weak shareholder rights. 
Agency costs emanating from ownership structure may also be mitigated through dividend policy. Managers have a greater incentive to engage in activities that do not serve the best interests of shareholders as their stake in the firm's equity diminishes (Jensen \& Meckling, 1976). Shareholders can instill discipline in project selection by demanding higher dividends. In support of this, Rozeff (1982), Ekbo and Verma (1994), Moh'd, Perry and Rimbey (1995), Dickens, Casey and Newman (2002) and Akhigbe and Whyte (2012) all uncover evidence of a statistically significant negative relationship between insider ownership and dividend payout.

The impact of large-block shareholders and institutional investors on the dividend decision is more ambiguous. These investors arguably occupy a middle ground between minority shareholders and executives in terms of their degree of control. Investors with substantial equity stakes have a greater incentive to supervise executive decision-making relative to smaller stakeholders. Large shareholders typically have superior access to management and can more efficiently monitor corporate activities. Their enhanced control relative to minority shareholders may serve as an alternate governance mechanism for dividends. This may particularly be the case for institutional investors. The presence of institutional investors may convey lower agency costs and/or good future growth prospects to potential investors, obviating the need for dividends (Short, Zhang, \& Keasey, 2002). However, large individual and institutional investors may not wish to engage in costly monitoring activities, but instead demand higher dividends to force firms into the capital markets where their activities are subject to public scrutiny. Large, controlling shareholders may impose agency costs on minority shareholders by extracting private perquisites and paying lower dividends (Schleifer \& Vishny, 1997). Wealth expropriation by large, controlling shareholders compels minority shareholders to push for higher dividends. The empirical evidence regarding the impact of principal and institutional shareholdings on dividend policy is mixed.

This study examines the role of ownership, board and corporate governance provisions on the dividend decision of 120 non-bank financial firms in 2011. Many studies modeling legal protection and governance quality utilize governance indexes, or composites which account for numerous governance provisions. This study simply examines the effectiveness of two provisions - cumulative voting and staggered board terms. In addition, although this study models insider, large-block individual outsider, and institutional ownership in a manner similar to prior research, it includes a type of activist investor that has received scant attention-hedge funds. The evidence indicates that insider ownership, institutional ownership and hedge fund ownership serve as substitute control mechanisms for dividends. In addition, of the two corporate governance provisions modeled, there is evidence that the cumulative voting provision serves as the more substantial governance substitute to dividends compared to staggered board terms.

The next section of the paper reviews the literature on ownership structure, board structure and governance provisions on dividend policy. Section 3 explains the hypothesis tests, section 4 describes the sample and data, and section 5 contains the empirical results.

\section{Literature Survey}

Since the seminal theoretical work of Modigliani and Miller (1961) asserting the irrelevance of dividend policy in perfect capital markets, there has been a great deal of attention paid to the importance of market frictions in determining dividend policy. One important area of inquiry has been the impact of agency problems on the dividend decision. As management's stake in the equity of the firm decreases, they have the incentive to pursue activities contrary to shareholder wealth maximization (Jensen \& Meckling, 1976). Managers with access to substantial free cash flow and poor investment opportunities may be tempted to use cash flow in ways that do not benefit shareholders, such as perquisite spending, empire building and investing in negative-NPV spending proposals (Jensen, 1986). Managers typically have a substantial portion of their wealth invested in the firm, and this lack of diversification encourages them to be more risk-averse in project selection, an outcome not favorable to shareholders (Easterbrook, 1984). By reducing the amount of cash available to managers, dividends encourage discipline with regard to project choice (Jensen, 1986). Distributing cash to shareholders may also require the firm to raise funds externally, subjecting the firm to the scrutiny of both current and potential investors (Easterbrook, 1984). Raising external financing increases the firm's transactions costs, so firms will select a dividend policy that minimizes total transactions costs and agency costs (Rozeff, 1982).

There may be a number of control mechanisms that shareholders can employ to replace the discipline and monitoring instilled by the dividend. Greater insider ownership may serve as a substitute control mechanism for the cash dividend. Executives who own equity shares have wealth interests more closely aligned with shareholders compared with executives who do not. As a result, shareholders of these firms should face lower monitoring and bonding costs. Many empirical studies have found that firms with higher insider stock ownership are less dependent on cash dividends as a disciplinary mechanism (Rozeff, 1982; Moh'd et al., 1995; Schooley \& 
Barney, 1994; Hu \& Kumar, 2004; Dickens et al., 2002, Wen \& Jia, 2010, Akhigbe \& Whyte, 2012).

From an agency perspective, it may be easier for firms with concentrated outside share holdings to more effectively discipline management. The presence of large-block shareholders may be viewed as an alternate governance mechanism to dividends. Large shareholders may have sufficient clout, through their voting power, board representation, and access to management, to mitigate the agency costs of free cash flow. Institutional investors, in particular, may have greater access to and are better positioned to persuade management. This may especially be the case for financial firms, since their business lines are more closely associated with the money management businesses of their institutional owners. Among institutional investors, hedge funds may serve as highly effective monitors given their presumably more activist perspective. Agency theory predicts that the presence of large-block shareholders mitigates the need to pay dividends. Given information asymmetries, the presence of large-block shareholders may also be viewed as a substitute signal to the dividend that the firm has favorable investment prospects (Zeckhauser \& Pound, 1990). This signaling explanation also predicts a negative association between large shareholdings and dividends.

On the other hand, effective monitoring of managers by large shareholders is costly and creates free-rider benefits. There may be insufficient incentives for large, controlling shareholders to provide the necessary monitoring and discipline, since they incur the costs of these actions, but share the benefits with other shareholders (Easterbrook, 1984). It may be more beneficial for large shareholders to invest passively and allow dividends and the threat of hostile takeovers to serve as governance devices. Furthermore, institutional investors may desire dividends for non-agency related reasons. They may face statutory obligations to pay operating expenses out of current income. Institutional investors also are not as tax-disadvantaged with regard to dividend income as most individual investors.

Shleifer and Vishny (1997) contend that firms with large shareholders in controlling positions may divert resources from smaller, non-controlling shareholders by paying lower dividends, maintaining higher asset balances and using those assets for a variety of reasons, such as private perquisite consumption, selling assets to themselves or other controlling interests at favorable prices, and other activities detrimental to non-controlling shareholders. In this case, large shareholders exacerbate the agency costs of equity to the detriment of smaller, non-controlling shareholders. Large shareholders prefer to extract private benefits in lieu of dividends, while minority shareholders prefer dividends as protection against wealth expropriation by large, controlling shareholders and management.

The evidence regarding the impact of large-block ownership on dividend payout is mixed. Rozeff (1982) and Moh'd et al. (1995) find that dividend payout significantly increases with ownership diffusion, as measured by the natural log of the number of common stockholders; Schooley and Barney (1994) get an identical result using dividend yield as the dependent variable. Hu and Kumar (2004) find that dividend payout significantly decreases in the presence of large shareholdings. Examining a sample of Italian firms, Mancinelli and Ozkan (2006) uncover a significant negative relationship between dividend payouts and the voting power of the largest shareholder. Harada and Nguyen (2011) identify a significant negative relationship between ownership concentration and dividend payout for Japanese firms. Renneborg and Trojanowski (2007) uncover a negative relationship between dividends and large-block holdings, in particular for financial institutional ownership. Wen and Jia (2010) also find that dividends are negatively related to institutional shareholdings. All of this research supports the view of dividends as a substitute control mechanism and as a signaling mechanism. However, both Zeckhauser and Pound (1990) and Grinstein and Michaely (2005) find no such relationship between institutions and dividend policy. Short et al. (2002), Moh'd et al. (1995) and Khan (2006) identify a positive association between institutional shareholdings and dividend payout. Thanatawee (2013) finds that higher institutional ownership increases both the likelihood and magnitude of dividend payouts based on a sample of Thai firms. Thanatawee (2013) also finds that the likelihood of a dividend payout is positively associated with ownership concentration and the percentage of stock held by the largest shareholder, particularly if the largest shareholder is an institution.

Corporate governance provisions, such as cumulative voting and staggered board elections, could have agency-related implications on dividend policy. The outcome versus substitution models from LaPorta et al. (2000) are useful in explaining the impact of governance provisions and legal protections on dividend payouts. According to the outcome model, governance provisions that enhance the legal protection of minority shareholders make it easier for those shareholders, perhaps through improved board representation, to prevent wealth expropriation by insiders. The enhanced influence that accrues to minority shareholders resulting from greater legal protection enables them to extract higher dividends. However, LaPorta et al. (2000) also assert that growth prospects act as a countervailing factor to this. Firms with good growth prospects tend to conserve more 
cash and make lower payouts, even in the presence of strong legal protections. These shareholders are more willing to allow management to exploit those prospects and to reinvest, with the anticipation of receiving higher future dividends.

Conversely, the substitution model asserts that managers for firms with weak legal protection will pay more dividends in order to develop a reputation of not expropriating shareholder wealth. The substitution model contends that firms with better legal protection and improved shareholder rights are less reliant on dividends as a control mechanism.

Of the two competing models, Laporta et al. (2000) find substantial evidence supporting the outcome model on empirical tests involving national governance provisions across 33 countries. Jiraporn et al. (2011) find that firms that have enhanced shareholder rights are more likely to pay dividends, and that those that do pay a dividend pay larger dividends. Using a sample of firms listed on the Toronto Stock Exchange, Adjaoud and Ben-Amir (2010) find that stronger shareholder rights lead to higher dividend payments, also supporting the outcome hypothesis. However, Jiraporn and Ning (2006) employ a governance index that incorporates 28 governance provisions to proxy the strength of shareholder rights. They find that firms that score high marks on the governance index (i.e., weak shareholder legal protections) pay more dividends, a result supporting the substitution model. Jo and Pan (2009) also provide evidence supporting the substitution model.

As regards to cumulative voting and staggered board elections, cumulative voting enhances shareholder rights, while staggered boards serve to preserve managerial entrenchment. If the outcome model is in effect, firms with cumulative voting will pay higher dividends, and firms with staggered board elections lower dividends. The reverse is the case if the substitution model is in effect. Jiraporn and Chintrakarn (2009) find that firms with staggered boards pay higher dividends, supporting the substitution hypothesis. To date the author is unaware of any empirical study that isolates the impact of cumulative voting on dividend policy.

Insider participation on the board of directors is important, particularly for complex organizations with high information asymmetries. Managers bring valuable specific knowledge to the strategic decision-making process. However, shareholders depend upon the discipline and enhanced monitoring that the presumably more independent outside board members provide. Outside board members have the incentive to establish a reputation as effective stewards for shareholders free from managerial influence and control (Fama \& Jensen, 1983). There is empirical evidence indicating that outside board members tend to serve the interests of shareholders (Rosenstein \& Wyatt, 1990; Brickley, Coles, \& Terry, 1994). Whether more independent boards produce higher or lower dividends depends upon whether the outcome model (dividends will increase) or the substitution model (dividends will decrease) prevails. Sharma (2011) finds a positive relationship between board independence and total payout, but a statistically weaker relationship with cash dividend payouts. Hu and Kumar (2004) find a positive and statistically significant relationship between greater board independence and the propensity to pay dividends. Jiraporn and Ning (2006) find that independent board representation has a positive and statistically significant relationship with dividend yield, but negative and insignificant with dividends-to-earnings.

\section{Model Specification and Variable Definitions}

The dependent variables are the dividend payout ratio, or dividends per share divided by earnings per share, and the dividend yield, or dividends per share divided by the price of the stock.

The EBITA margin, or earnings before interest, taxes, and amortization expenses divided by sales, is intended to measure the firm's ability to generate free cash flow and profits. Firms with higher free cash flow are able to distribute more cash to shareholders, and, therefore, are expected to pay more dividends.

Firm size is measured by the natural log of total assets. This is in accord with many other studies, including, more recently, Sharma (2011), Adjaoud and Ben Amir (2010), Thanatawee (2013) and Akhigbe and Whyte (2012). There are reasons why larger firms should pay more dividends. To the extent that firm size serves as a proxy for the risk of bankruptcy, larger firms should have a lower risk of bankruptcy and, therefore, a greater ability to pay dividends. Also, larger firms generally have greater access to the capital markets and are presumably better able to raise external financing in the event of a funding shortage.

Cash flow volatility and the systematic risk of the firm's equity is modeled by the firm's two-year beta. According to Rozeff (1982), at any given level of dividends, firms with high operating and financial leverage will face higher cash flow volatility, which will cause them to more frequently enter the external markets for financing and create higher transactions costs. To avoid these costs, risky firms will lower dividend payouts and rely more on internal funding. Rozeff (1982), Schooley and Barney (1994) and Harada and Nguyen (2011) find a negative and statistically significant relationship between the beta and dividends. 
The price-to-book ratio serves as a proxy for the firm's investment prospects. Firms with higher price-to-book values have better growth prospects and are, therefore, more likely to retain cash and pay less dividends compared with firms with limited growth prospects. This proxy for investment prospects is used in Hu and Kumar (2004), Manzinelli and Ozcan (2006) and Sharma (2011).

CEO ownership, or the percentage of stock owned by the CEO, is predicted to be negatively related to dividends. Executive stock ownership may serve as an important device in reducing agency friction in situations in which information asymmetries prevent the board from effectively monitoring the firm's cash management and capital spending activities (White, 1996). Firms in which the CEO owns shares should have less agency problems of equity and, therefore, less of a need to use the dividend as a disciplining mechanism. Both Hu and Kumar (2004) and Schooley and Barney (1994) find that dividend yield has a significant negative relationship with CEO stock ownership.

Independent board \%, or the percentage of external board members, could be positively or negatively related to dividends. Greater outside shareholder representation improves the ability of shareholders to extract more dividends (outcome model and the free cash flow hypothesis (Jensen, 1986) ) but may also serve as an alternate control mechanism to dividends (substitution model). Sharma (2011) uses a continuous variable, as in this study, while $\mathrm{Hu}$ and Kumar (2004) use a binary variable to control for board independence.

Principal ownership, or the percentage of stock owned by the largest individual, non-institutional investor, and institutional ownership, or the percentage of stock held by institutions, could have a negative or positive sign, depending upon whether large-block individual shareholders and institutional investors serve as substitutes for dividends or whether they are essentially passive investors due to free-rider and dividend preference considerations. Moh'd, Perry \& Rimbey (1995), Short, Zhang \& Keasey (2002), Khan (2006), Renneborg and Trojanowski (2007), Wen and Jia (2010) and Thanatawee (2013) control for institutional ownership. Hedge fund ownership, or the percentage of stock held by hedge funds, is predicted to have an inverse relationship with dividends.

Table 1. Description of variables

\begin{tabular}{|c|c|}
\hline Variable & Description \\
\hline \multicolumn{2}{|l|}{ Dependent variables: } \\
\hline Dividend payout ratio & Dividends per share divided by earnings per share \\
\hline Dividend yield & Dividends per share divided by the market price of stock \\
\hline \multicolumn{2}{|c|}{ Ownership and governance variables: } \\
\hline CEO ownership (-) & Percentage of common stock owned by the chief executive officer; \\
\hline Principal ownership (+/-) & Percentage of stock owned by the largest individual, non-institutional investor; \\
\hline Hedge fund ownership (-) & Percentage of stock held by hedge funds as a group; \\
\hline Institutional ownership (+/-) & Percentage of stock held by all institutional investors; \\
\hline Independent board $\%(+/-)$ & Percentage of total board positions held by independent directors; \\
\hline Cumulative voting binary $(+/-)$ & $=1$ if the company has cumulative voting, 0 otherwise; \\
\hline Staggered board binary $(+/-)$ & $=1$ if the company has staggered board terms, 0 otherwise; \\
\hline \multicolumn{2}{|l|}{ Firm control variables: } \\
\hline EBITA margin $(+)$ & Earnings before interest, taxes and amortization expenses divided by sales; \\
\hline Firm size $(+)$ & Natural log of total assets; \\
\hline Beta $(-)$ & Two-year beta for the firm; \\
\hline Price-to-book ratio (-) & Market price of the stock divided by book value per share; \\
\hline
\end{tabular}

The signs on the cumulative voting dummy variable and the staggered board dummy variable are indeterminate and depend on whether the presence of the governance provision generates either outcome or substitution effects. Cumulative voting serves to enhance the rights of minority shareholders, while staggered boards better serve entrenched management and large, controlling shareholders. The outcome model predicts that firms with cumulative voting pay higher dividends, and firms with staggered boards pay lower dividends. The 
substitution model predicts lower dividends with cumulative voting and higher dividends with staggered boards. According to the substitution model, management is willing to pay more dividends in order to establish a reputation in the capital markets of not taking advantage of smaller, non-controlling shareholders. Jiraporn and Chintrakarn (2009) control for the effect of staggered board terms on dividends.

Table 1 contains the dependent and explanatory variables used in the empirical model to determine the impact of various agency-theoretic and firm characteristic control variables on dividend policy. The parenthesis following the independent variable name contains the hypothesized sign(s).

\section{Sample and Descriptive Statistics}

The original sample is drawn from the S\&P Capital IQ database. The sample originally started as 212 financial services firms trading on the NYSE, NASDAQ and AMEX during 2011. Firms were excluded if a complete set of data could not be obtained. Firms were also removed if the dividend payout ratio exceeded $150 \%$, since it is assumed that these firms are much more likely to be experiencing extraordinary changes in dividends or earnings beyond the scope of what is modeled in this paper. This leaves a remaining sample of 120 firms, and 112 firms when the staggered board dummy is included. The sample firms are drawn across 24 SIC codes, with the largest representations from real estate investment trusts (REITS), (33 firms or $27.5 \%$ of the sample), fire, marine and casualty insurance ( 24 firms or $20 \%$ of the sample) and life insurance (10 firms or $8.33 \%$ of the sample).

Table 2 contains the means, medians and standard deviations of all of the variables used in this study. The dependent variables, EBITA margin, ownership characteristics and independent board $\%$ are stated in percentages. Total assets are in millions of U.S. dollars. Two measures of dividends are used as dependent variables-the dividend yield (dividends per share divided by the market price of the stock) and the dividend payout ratio (dividends per share divided by earnings per share).

Table 2. Sample means, medians and standard deviations

\begin{tabular}{llll} 
& Mean & Median & $\begin{array}{c}\text { Standard } \\
\text { Deviation }\end{array}$ \\
\hline $\begin{array}{l}\text { a. Dependent Variables } \\
\text { Dividend payout ratio }\end{array}$ & 55.003 & 42.1 & 45.284 \\
Dividend yield & 4.452 & 3.04 & 4.647 \\
b. Firm Characteristics & & & \\
EBITA margin & 31.802 & 24.5 & 22.308 \\
Total assets & 29,587 & 4,193 & 91,521 \\
Beta & 0.9924 & 0.9125 & 0.4284 \\
Price-to-book ratio & 1.9988 & 1.375 & 1.8698 \\
c. Ownership Characteristics & & & \\
CEO ownership & 1.655 & 0.373 & 3.742 \\
Principal ownership & 3.646 & 0.793 & 7.135 \\
Hedge funds ownership & 3.205 & 1.745 & 3.559 \\
Institutional ownership & 74.927 & 80.545 & 28.29 \\
d. Board and Governance Characteristics & & & \\
Independent board \% & 80.309 & 83.33 & 10.234 \\
Cumulative voting dummy & 0.0667 & 0 & 0.2505 \\
Staggered board dummy & 0.4821 & 0 & 0.5019 \\
\hline
\end{tabular}

Note: $\mathrm{N}=120$.

The dividend yield has a sample average of 0.0445 ( 0.0304 median) and the dividend payout ratio has a sample average of 0.55 ( 0.421 median). Of the three most represented industry sub-sectors in the sample, REITs post the highest average dividend yields and payout ratios ( $4.30 \%$ and $103.75 \%$, respectively), compared with fire, marine 
and casualty (3.17\% and $36.77 \%)$ and life insurance companies (2.0\% and $17.99 \%)$.

The average firm has total assets of $\$ 29.6$ billion and median total assets at $\$ 4.2$ billion, indicating that there is a large size variation in the sample (see Table 2). The largest firms are in life insurance, with an average of $\$ 160$ billion in total assets. The sample firms are very profitable overall, with an average EBITA margin of $31.8 \%$. The investment offices and closed-end investment companies sub-sectors have the highest margins at $72.3 \%$ and $61.6 \%$, respectively. The price-to-book ratio, which is used to measure growth prospects, has a sample average of 2.0 , and the average 2-year beta is at 0.99 .

With regard to the board, ownership and governance variables, referring to Table 2 , the average percentage of external, or independent, directors is $80.31 \%$. The average CEO and largest individual shareholdings are at $1.66 \%$ and $3.65 \%$, respectively. Hedge fund holdings averaged $3.2 \%$ and institutions, which include hedge funds, held a mean $75 \%$ of outstanding shares. Approximately $6.7 \%$ of the firms have a cumulative voting provision in the corporate charter.

The correlation coefficients are reported in the Appendix. Both dividend yield and dividend payout ratio are positively correlated with each other $(+0.245)$. Both dependent variables are positively correlated with the EBITA margin $(+0.345$ for yield and +0.371 for payout) and are negatively correlated with total assets, beta, CEO ownership, hedge fund shareholdings, independent board representation and the cumulative voting dummy. The price-to-book ratio is essentially uncorrelated to dividend yield $(+0.003)$ and has a positive correlation with dividend payout $(+0.288)$. Dividend yield is negatively correlated $(-0.256)$ and dividend payout is positively correlated $(+0.107)$ with institutional shareholdings. Total assets has a weak negative correlation with CEO $(-0.115)$ and principal (-0.138) ownership, and a weak positive correlation with hedge fund $(+0.095)$ and institutional $(+0.051)$ shareholdings. The highest correlation is between CEO and principal ownership $(+0.458)$, not a surprising result since the principal ownership term includes both executive and outside owners. The lowest correlation occurs between principal and institutional shareholdings (-0.538), followed by CEO and institutional shareholdings (-0.357). The cumulative board dummy has correlations with the other explanatory variables ranging between +0.20 and -0.19 , while the staggered board dummy has correlations with the other explanatory variables ranging from +0.15 and -0.19 . The bulk of the correlations have an absolute value less than 0.30 . Taken together, the correlation matrix does not suggest the presence of multicollinearity in the sample.

\section{Regression Results}

The results from the regression analysis are presented in Table 3. Industry dummies are used to control for industry-specific effects, and account for the relatively high R-squareds in all four equations. Equations (1) and (2) explain about 85 percent of the cross-sectional variation in dividend yields. The EBITA margin, included to control for cash flow, is negatively related to dividend payout but is statistically insignificant. However, this margin is positively and significantly related to dividend yield, a result similar to Jiraporn and Ning (2006). Firm size, modeled by the natural log of total assets, has a negative sign in three of the four equations, but is statistically insignificant throughout.

The beta is included to account for business and financial risk, which has been found to have an important impact on dividend policy (Rozeff, 1982; Moh'd, Perry, \& Rimbey, 1995). The beta has the predicted negative sign in equations (2), (3), and (4) but insignificant, as in Casey and Dickens (2000). The price-to-book ratio serves as a proxy for investment prospects, and has the predicted negative sign in the dividend yield equations (1) and (2), a result similar with Mancinelli and Ozkan (2006).

In equation (2), in which the dividend yield is the dependent variable, the cumulative voting dummy produces a negative and statistically significant coefficient (t-stat $=-2.742$ and significant at the $1 \%$ level). The cumulative voting dummy is also negative and significant in equation (4) which uses the dividend payout ratio as the dependent variable ( $t$-stat $=-2.639$ and significant at the $1 \%$ level). The results suggest that cumulative voting serves as a substitute governance mechanism for dividends - firms that have a cumulative voting system are less reliant on dividends to discipline management and large shareholders compared with firms that have a majority voting system. However, the same case cannot be made for firms with a staggered board elections system. Although the staggered board dummy. 
Table 3. Regression results of dividend yield and dividend payout

\begin{tabular}{|c|c|c|c|c|}
\hline & -1 & -2 & -3 & -4 \\
\hline Dependent & Dividend & Dividend & Dividend & Dividend \\
\hline Variable & Yield & Yield & Payout & Payout \\
\hline \multirow[t]{2}{*}{ Constant } & $7.012^{* * *}$ & $8.384^{* * *}$ & $81.540^{* * *}$ & $55.017^{* * *}$ \\
\hline & $(5.540)$ & $(2.842)$ & $(3.071)$ & $(14.410)$ \\
\hline \multirow[t]{2}{*}{ EBITA margin } & $0.053^{* * *}$ & $0.043^{*}$ & -0.352 & -0.22 \\
\hline & $(2.729)$ & (1.914) & $(-1.374)$ & $(-0.681)$ \\
\hline \multirow[t]{2}{*}{ Firm size } & -0.174 & -0.063 & -0.564 & 0.314 \\
\hline & $(-1.085)$ & $(-0.440)$ & $(-0.256)$ & $(0.137)$ \\
\hline \multirow[t]{2}{*}{ Beta } & 0.276 & -0.425 & -13.166 & -12.281 \\
\hline & $(0.393)$ & $(-0.660)$ & $(-1.222)$ & $(-1.108)$ \\
\hline \multirow[t]{2}{*}{ Price-to-book ratio } & $-0.225^{*}$ & $-0.207^{*}$ & 0.131 & 0.346 \\
\hline & $(-1.683)$ & $(-1.656)$ & $(0.051)$ & $(0.137)$ \\
\hline \multirow[t]{2}{*}{ CEO ownership } & $-0.155^{* * *}$ & $-0.155^{* *}$ & $-1.765^{*}$ & -1.395 \\
\hline & $(-2.720)$ & $(-2.258)$ & $(-1.756)$ & $(-1.290)$ \\
\hline \multirow[t]{2}{*}{ Principal ownership } & 0.068 & 0.06 & -0.392 & -0.183 \\
\hline & $(0.945)$ & $(0.785)$ & $(-0.584)$ & $(-0.273)$ \\
\hline \multirow[t]{2}{*}{ Hedge fund ownership } & $-0.105^{*}$ & $-0.149^{* * *}$ & $-1.244^{*}$ & $-1.792^{* *}$ \\
\hline & $(-1.958)$ & $(-2.704)$ & $(-1.659)$ & $(-2.013)$ \\
\hline \multirow[t]{2}{*}{ Institutional ownership } & $-0.030^{* * *}$ & $-0.033^{* * *}$ & -0.018 & -0.031 \\
\hline & $(-2.682)$ & $(-3.019)$ & $(-0.098)$ & $(-0.159)$ \\
\hline \multirow[t]{2}{*}{ Independent board \% } & --- & -0.013 & --- & 0.14 \\
\hline & & $(-0.500)$ & & $(0.337)$ \\
\hline \multirow[t]{2}{*}{ Cumulative voting dummy } & --- & $-1.834^{* * *}$ & --- & $-21.518^{* * *}$ \\
\hline & & $(-2.742)$ & & $(-2.639)$ \\
\hline \multirow[t]{2}{*}{ Staggered board dummy } & --- & 0.305 & --- & 7.089 \\
\hline & & $(0.715)$ & & $(0.885)$ \\
\hline Industry dummies & Yes & Yes & Yes & Yes \\
\hline R-squared & 0.846 & 0.845 & 0.621 & 0.651 \\
\hline F-statistic & 17.83 & 14.681 & 5.33 & 5.044 \\
\hline Prob(F-statistic) & 0 & 0 & 0 & 0 \\
\hline $\mathrm{N}$ & 120 & 112 & 120 & 112 \\
\hline
\end{tabular}

T-statistic is in parenthesis. ${ }^{* * *}, * *$ and $*$ represent $1 \%, 5 \%$ and $10 \%$ significance levels. Results obtained using White heteroskedasticity-consistent standard errors \& covariance.

With a staggered board elections system. Although the staggered board dummy have positive signs in both equations, suggesting support for the substitution model, they are statistically insignificant. These two results suggest that when comparing the relative importance of these two specific governance mechanisms that shareholders for financial firms regard the cumulative voting provision to be more effective. The coefficients on the independent board participation variable are insignificant in both equations (2) and (4). The presence of the independent board representation variable does not have a material impact on the cumulative voting and staggered board results. With regard to the ownership variables, although principal ownership is insignificant throughout all four equations, the same is not so with regard to the other ownership control variables. CEO ownership, hedge fund ownership and aggregate institutional ownership show negative and statistically 
significant effects in equations (1) and (2), the dividend yield equations, with the most significance in the institutional ownership variable. Although the statistical significance of CEO and institutional ownership diminishes in the dividend payout equations (3) and (4), hedge fund ownership maintains its significance in these equations as well. The results overall confirms the negative association between CEO ownership and dividends found in Hu and Kumar (2004) and Schooley and Barney (1994). The evidence also indicates that for these firms, institutional owners and, in particular, hedge funds serve as a viable substitute control mechanism for dividends.

\section{Conclusion}

This study finds broad support for the agency explanation of dividends. Agency theory contends that agency conflict increases when managerial ownership is low or when outsider share diffusion is high. Shareholder rights may also be compromised in the presence of corporate governance provisions that arguably serve to abet managerial and/or large, controlling shareholder entrenchment, such as majority voting or staggered board election structures. The evidence in this study indicates that higher levels of CEO, hedge fund and aggregate institutional ownership are inversely associated with dividend yields and, to a lesser extent, dividend payout. In addition, the evidence shows that dividends have a statistically significant inverse relationship with cumulative voting, and a positive but statistically insignificant relationship with staggered boards. These results suggest that from a governance and control perspective, the cumulative voting provision is the more effective of the two. Although previous studies have used indexes of governance conditions which incorporate the impact of numerous governance provisions simultaneously, developing a model that can determine the relative importance of not only cumulative voting and staggered boards but the variety of governance provisions that appear in these indexes is a topic worthy of future research.

\section{References}

Adjaoud, F., \& Ben-Amir, W. (2010). Corporate governance and dividend policy: Shareholders protection or expropriation? Journal of Business, Finance \& Accounting, 37, 648-667. http://dx.doi.org/10.1111/j.1468-5957.2010.02192.x

Brickley, J., Coles, J., \& Terry, R. (1994). The board of directors and the enactment of poison pills. Journal of Financial Economics, 35, 371-390. http://dx.doi.org/10.1016/0304-405X(94)90038-8

Dickens, R. N., Casey, K. M., \& Newman, J. A. (2002). Bank dividend policy: Explanatory factors. Quarterly Journal of Business and Economics, 41, 3-12.

Easterbrook, F. H. (1984). Two agency-cost explanations of dividends. American Economic Review, 74, $650-659$.

Eckbo, B. E., \& Verma, S. (1994). Managerial ownership, voting power and cash dividend policy. Journal of Corporate Finance, 1, 33-62. http://dx.doi.org/10.1016/0929-1199(94)90009-4

Fama, E., \& Jensen, M. (1983). Separation of ownership and control. Journal of Law and Economics, 26, 301-325. http://dx.doi.org/10.1086/467037

Grinstein, Y., \& Michaely, R. (2005). Institutional holdings and payout policy. Journal of Finance, 60, 1389-1426. http://dx.doi.org/10.1111/j.1540-6261.2005.00765.x

Harada, K., \& Nguyen, P. (2011). Ownership conception and dividend policy in Japan. Managerial Finance, 37, 362-419. http://dx.doi.org/10.1108/03074351111115313

Hu, A., \& Kumar, P. (2004). Managerial entrenchment and payout policy. Journal of Financial and Quantitative Analysis, 39, 759-790. http://dx.doi.org/10.1017/S0022109000003203

Jensen, M. (1986). Agency costs of free cash flow, corporate finance and takeovers. American Economic Review, 76, 323-339.

Jensen, M., \& Meckling, W. H. (1976). Theory of the firm: Managerial behavior, agency costs and ownership structure. Journal of Financial Economics, 3, 305-360. http://dx.doi.org/10.1016/0304-405X(76)90026-X

Jiraporn, P., \& Chintrakarn, P. (2009). Staggered boards, managerial entrenchment and dividend policy. Journal of Financial Services Research, 36, 1-19. http://dx.doi.org/10.1007/s10693-009-0059-6

Jiraporn, P., \& Ning, Y. (2006). Dividend policy, shareholder rights and corporate governance. Journal of Applied Finance, (Fall/Winter), 24-36.

Jiraporn, P., Kim, J., \& Kim, Y. S. (2011). Dividend payouts and corporate governance quality: An empirical investigation. The Financial Review, 46, 251-279. http://dx.doi.org/10.1111/j.1540-6288.2011.00299.x 
Jo, H., \& Pan, C. (2009). Why are firms with entrenched managers more likely to pay dividends? Review of Accounting and Finance, 8, 87-116. http://dx.doi.org/10.1108/14757700910934256

Khan, T. (2006). Company dividends and ownership structure: Evidence from UK panel data. The Economic Journal, 116, 172-189. http://dx.doi.org/10.1111/j.1468-0297.2006.01082.x

LaPorta, R., Lopez-De Salinas, F., Schleifer, A., \& Vishny, R. (2000). Agency problems and dividend policy around the world. Journal of Finance, 55, 1-33. http://dx.doi.org/10.1111/0022-1082.00199

Mancinelli, L., \& Ozkan, A. (2006). Ownership structure and dividend policy: Evidence from Italian firms. European Journal of Finance, 12, 265-282. http://dx.doi.org/10.1080/13518470500249365

Modigliani, F., \& Miller, M. (1961). Dividend policy, growth and the valuation of shares. Journal of Business, 34, 411-433. http://dx.doi.org/10.1086/294442

Moh'd, M., Perry, L., \& Rimbey, J. (1995). An investigation of the dynamic relationship between agency theory and dividend policy. The Financial Review, 30, 367-385. http://dx.doi.org/10.1111/j.1540-6288.1995.tb00837.x

Renneboog, L., \& Trojanowski, G. (2007). Control structures and payout policy. Managerial Finance, 33, 43-64. http://dx.doi.org/10.1108/03074350710715809

Rosenstein, S., \& Wyatt, J. (1990). Outside directors, board independence and shareholder wealth. Journal of Financial Economics, 26, 175-191. http://dx.doi.org/10.1016/0304-405X(90)90002-H

Rozeff, M. (1982). Growth, beta and agency costs as determinants of dividend payout ratios. Journal of Financial Research, 5, 249-259.

Schooley, D., \& Barney, Jr. L. D. (1994). Using dividend policy and managerial ownership to reduce agency costs. The Journal of Financial Research, 17, 363-373.

Sharma, V. (2011). Independent directors and the propensity to pay dividends. Journal of Corporate Finance, 17 , 1001-1015. http://dx.doi.org/10.1016/j.jcorpfin.2011.05.003

Shleifer, A., \& Vishny, R. (1997). Large shareholders and corporate control. Journal of Political Economy, 95, $461-488$.

Thanatawee, Y. (2013). Ownership structure and dividend policy: Evidence from Thailand. International Journal of Economics and Finance, 5, 121-132.

Wen, Y., \& Jia, J. (2010). Institutional ownership, managerial ownership and dividend policy in bank holding companies. International Review of Accounting, Banking and Finance, 2, 8-21.

White, L. F. (1996). Executive compensation and dividend policy. Journal of Corporate Finance, 2, 335-358. http://dx.doi.org/10.1016/0929-1199(96)00003-X

Zeckhauser, R. J., \& Pound, J. (1990). Are large shareholders effective monitors? An investigation of share ownership and corporate performance. In Hubbard, R. G. (Ed.), Asymmetric information, corporate finance and investment (pp. 149-180). University of Chicago Press. 


\section{Appendix}

Appendix 1. Pearson correlation coefficients

\begin{tabular}{|c|c|c|c|c|c|c|c|c|c|c|c|c|c|}
\hline & -1 & -2 & -3 & -4 & -5 & -6 & -7 & -8 & -9 & -10 & -11 & -12 & -13 \\
\hline Dividend yield (1) & 1.000 & 0.245 & 0.345 & -0.116 & -0.207 & 0.003 & -0.047 & 0.005 & -0.081 & -0.256 & -0.102 & -0.113 & 0.047 \\
\hline $\begin{array}{l}\text { Dividend payout } \\
\text { (2) }\end{array}$ & & 1.000 & 0.371 & -0.197 & -0.171 & 0.288 & -0.151 & -0.126 & -0.347 & 0.107 & -0.044 & -0.105 & 0.123 \\
\hline EBITA margin (3) & & & 1.000 & -0.202 & -0.171 & 0.178 & -0.043 & -0.146 & -0.182 & -0.235 & -0.206 & -0.032 & 0.149 \\
\hline Total assets (4) & & & & 1.000 & 0.397 & -0.16 & -0.115 & -0.138 & 0.095 & 0.051 & 0.181 & -0.055 & 0.019 \\
\hline Beta (5) & & & & & 1.000 & -0.046 & -0.324 & -0.296 & 0.183 & 0.297 & 0.131 & -0.19 & 0.076 \\
\hline $\begin{array}{l}\text { Price-to-book ratio } \\
\text { (6) }\end{array}$ & & & & & & 1.000 & -0.036 & -0.032 & -0.079 & 0.073 & 0.058 & 0.011 & 0.004 \\
\hline $\begin{array}{l}\text { CEO ownership } \\
\text { (7) }\end{array}$ & & & & & & & 1.000 & 0.458 & -0.106 & -0.357 & -0.351 & 0.201 & -0.085 \\
\hline $\begin{array}{l}\text { Principal } \\
\text { ownership (8) }\end{array}$ & & & & & & & & 1.000 & -0.158 & -0.538 & -0.276 & 0.135 & -0.19 \\
\hline $\begin{array}{l}\text { Hedge fund } \\
\text { ownership (9) }\end{array}$ & & & & & & & & & 1.000 & 0.169 & 0.167 & -0.146 & 0.069 \\
\hline $\begin{array}{l}\text { Institutional } \\
\text { ownership (10) }\end{array}$ & & & & & & & & & & 1.000 & 0.329 & -0.04 & 0.004 \\
\hline $\begin{array}{l}\text { Independent } \\
\text { board \% (11) }\end{array}$ & & & & & & & & & & & 1.000 & 0.021 & 0.055 \\
\hline $\begin{array}{l}\text { Cumulative voting } \\
\text { dummy (12) }\end{array}$ & & & & & & & & & & & & 1.000 & -0.059 \\
\hline $\begin{array}{l}\text { Staggered board } \\
\text { dummy (13) }\end{array}$ & & & & & & & & & & & & & 1.000 \\
\hline
\end{tabular}

In which:

Dividend yield $=$ dividend per share divided by the market price of the stock;

Dividend payout $=$ dividend per share divided by earnings per share;

EBITA margin = earnings before interest, taxes, depreciation and amortization charges divided by sales;

Price-to-book ratio $=$ market price of the stock divided by book value per share;

CEO ownership $=$ percentage of stock owned by the Chief Executive Officer;

Principal ownership = percentage of stock owned by the largest individual, non-institutional owner;

Hedge fund ownership = percentage of stock held by hedge funds;

Institutional ownership $=$ percentage of stock held by institutions;

Independent board $\%=$ percentage of board directors that are external;

Cumulative voting dummy $=1$ if the firm has cumulative voting for board seats, 0 otherwise;

Staggered board dummy $=1$ if the firm has a staggered board structure, 0 otherwise.

\section{Copyrights}

Copyright for this article is retained by the author(s), with first publication rights granted to the journal.

This is an open-access article distributed under the terms and conditions of the Creative Commons Attribution license (http://creativecommons.org/licenses/by/3.0/). 